I Universidade Federal do Rio de Janeiro (UFRJ), Programa

de Pós-Graduação em Sociologia e Antropologia, Rio de Janeiro, RJ, Brasil

mauriciohoelz@ufrj.br

Maurício Hoelz'

\title{
O ESPELHO DE MACUNAÍMA: \\ O ENSAIO SOBRE MÚSICA BRASILEIRA \\ PARA ALÉM DO NACIONALISMO
}

Não sou nacionalista, Pastor Fido, sou simplesmente nacional.
Nacionalismo é uma teoria política, mesmo em arte.
Perigosa para a sociedade, precária para a inteligência.
Janjão, em O banquete.

\section{PONTEIO}

Entre as décadas de I920 e I940 diversas interpretações do Brasil foram formuladas por meio do gênero ensaístico, em que a orientação sociológica ganhava proeminência, e também em diferentes modalidades de ficção e mesmo de manifestações artísticas. A pregnância do movimento modernista nesse contexto intelectual foi tão significativa, que, embora longe de esgotar o universo de questões em jogo, acabou conformando nossa própria compreensão do período. Tal imposição resulta, em parte, tanto do caráter de movimento cultural do modernismo (Botelho, 20I7), que imprimiu ao curso dos acontecimentos contemporâneos um sentido que se tornaria hegemônico, quanto de um exitoso trabalho historiográfico e crítico posterior (Moreschi, 20 го). O legado intelectual e artístico dessas narrativas direta ou indiretamente modernistas vem desde então sendo atualizado por meio de leituras que ou as retomam para propor novas visões sobre o país, ou, de maneira paradoxal, recusam criticamente sua validade. Seja como for, esses dispositivos lograram estabelecer comunicações com diferentes temporalidades, extrapolando as fronteiras acadêmicas e contribuindo para forjar, reflexivamente, modos de pensar e sentir o Brasil e de nele atuar ainda hoje vigentes.

Em relação aos chamados ensaios de intepretação do Brasil, por exemplo, André Botelho (2010) problematizou a visão homogeneizadora que as ciências sociais institucionalizadas cristalizaram sobre essa forma de imaginação so- 
ciológica. Nesse estudo, Botelho argumenta que, embora distingam os ensaios de modalidades anteriores e posteriores de pensamento social, o compartilhamento de determinados aspectos e o pertencimento sincrônico não representam critérios suficientes para os definir como uma unidade fixa com base em características cognitivas e narrativas exclusivas, tampouco de um ponto de vista contextual mais amplo. Por isso, buscar qualquer unidade para os ensaios de interpretação do Brasil escritos entre I 920 e I 940 constitui, na melhor das hipóteses, um movimento analítico de atribuição e não de inferência, como algumas vezes tem sido feito; e trata-se de problema que se colocou a posteriori, mas que acabou por redefinir seu lugar e seu sentido na cultura brasileira.

Concordando com essa hipótese, retomo aqui, particularmente, a sugestão de que até uma tópica como a da identidade nacional, inegavelmente central nos anos I920-I940, não é estável nas diferentes interpretações do Brasil desse período, como se formassem um todo coerente ou contínuo; tampouco define a priori a economia interna de suas narrativas, como se o mero fato de elas pertencerem a um mesmo contexto sincrônico sobredeterminasse os sentidos dessas intepretações, que, ainda quando perscrutadas exclusivamente do ponto de vista temático, não são passíveis de unificação. Basta lembrar, por exemplo, Raízes do Brasil, de Sérgio Buarque de Holanda, em que, mais do que a busca de uma identidade nacional que pudesse singularizar a sociedade brasileira em relação a outras experiências históricas, estariam em jogo as tensões entre formas de sociabilidades tradicionais e modernas no devir da nossa vida social, engendrando uma série de impasses e possibilidades para seu presente e seu futuro.

Tendo isso em vista, proponho no presente estudo uma releitura analítica e a contrapelo do Ensaio sobre música brasileira, de Mário de Andrade, publicado no final de 1928 pela I. Chiarato \& Cia de São Paulo e frequentemente tomado como esteio de seu nacionalismo musical. Embora faltem dados concretos sobre a recepção do livro - um estudo de fôlego a esse respeito ainda está por ser feito -, a literatura pertinente disponível (entre outros, Lisbôa, 2015; Toni, 20I5; Hamilton-Tyrrel, 2005; Contier, I995; Alvarenga, I974; Coli, I990; Luper, I965) é unânime em afirmar o impacto duradouro do livro sobre o público-alvo que se colocava no seu horizonte de expectativas - os jovens artistas, sobretudo os compositores, mas também musicólogos e alunos; livro que, ao codificar pioneiramente uma agenda para a música erudita do Brasil, logo se tornaria um clássico. Em trabalho de referência sobre o Ensaio, Arnaldo Contier (I995) evoca uma série de expressões emblemáticas que remetem ao caráter normativo e ideológico do texto. Refere-se a ele como "manifesto", devido a seu conteúdo programático polêmico e doutrinário-dogmático; como a "Bíblia" dos compositores nacionalistas brasileiros, aos quais o papa do futurismo teria feito "pregação missionária" visando conscientizá-los de seus "erros", tais como: exotismo, individualismo exacerbado, mimetismo, apologia do tradicionalismo musical 
europeu; ou até como a "nova carta" de descobrimento do Brasil, por meio da qual, de um lado, denunciaria o mimetismo dos artistas brasileiros em relação às escutas "tradicionais" da música europeia e, de outro, lançaria uma "exortação cívico-patriótica" a fim de persuadir emotivamente o leitor-artista, convocando-o a pesquisar, resgatar e sorver a rica e variada fonte do folclore - as falas musicais dos excluídos sociais, o "povo inculto", desconhecidas da elite culta -, bem como a desempenhar sua função social na nacionalização da música erudita brasileira e na "construção" de uma "Escola Nacionalista de Composição capaz de consolidar um polo cultural no Brasil, independentemente dos principais centros europeus" (Contier, I995: 9I). Segundo Contier, o Ensaio lograria tanto redefinir o "atraso" imputado pelas elites republicanas da belle époque tropical à cultura popular quanto sintetizar o anseio de compositores, intérpretes e intelectuais pela utopia do "som nacional", por um "retrato sonoro do Brasil". Diz Mário no livro: "Todo artista brasileiro que no momento atual fizer arte brasileira é um ser eficiente com valor humano. O que fizer arte internacional ou estrangeira, si não for genio, é um inutil, um nulo. E é uma reverendissima bêsta" (Andrade, I972: I9). Essa frase contundente, conforme defende Contier (I995: 86), teria virado, nas décadas subsequentes, "o lema ou a bandeira de todo artista erudito ou popular preocupado com a internalização das chamadas 'raízes' na música brasileira 'autêntica'” e com a "identidade nacional".

Esse exemplo, que poderia ser multiplicado à saciedade na fortuna crítica, nos permite indagar se o foco sobre a dimensão normativa do texto não teria acabado por cronicamente minimizar, senão eclipsar, sua dimensão propriamente cognitiva, erigindo nesse passo o seu famigerado nacionalismo em parti pris. Embora tenha sido comumente identificado como principal peça ideológica de rotinização do projeto nacionalista de Mário (cf. Contier, I995), se tomamos o devido cuidado com o léxico comprometido com o contexto da época ("raça", "entidade nacional" etc.), podemos surpreender no Ensaio uma concepção sofisticada da constituição das identidades coletivas como processo eminentemente relacional que se constrói nas fissuras e nas negociações que articulam o interno e o externo, o particular e o geral, negando, assim, que a representação do brasileiro, colonizado, fosse uma questão de gradiente de autenticidade e complexidade. Assim, este exercício de leitura desse texto em chave macunaímica, por assim dizer, visa matizar e a desestabilizar o sentido exclusivamente "ontológico" ao qual acabou atrelado. Para tanto, restituo o sentido contingente do tão glosado "nacionalismo" do autor, demonstrando que, assim como em outros ensaios que se tornaram célebres por suas "interpretações do Brasil" na década de I920, a exemplo de Populações meridionais do Brasil (I920) de Oliveira Vianna, é possível distinguir analiticamente no Ensaio a dimensão propriamente cognitiva daquela normativa, isto é, o plano do diagnóstico do prognóstico, não obs tante eles se encontrem empiricamente imbricados na fatura textual. Assim procedendo, qualifico o que denomino nacionalismo instrumental de Mário: não 
um fim substantivo a ser teleológica e normativamente perseguido, mas apenas um meio - "brasileirismo de estandarte útil" - para a realização de um fim que se quer cosmopolita. Dito de outro modo, em vez de pressupor o sentido e o significado do nacionalismo como dado, sugiro que ele era muito mais aberto e, por que não?, ambíguo, no contexto da publicação do Ensaio: não apenas no livro de Mário como na própria sociedade, ambos estavam em construção e disputa. Antonio Candido (I995), aliás, já nos advertia sobre as "flutuações" históricas da palavra nacionalismo entre nós.

Esse ângulo enviesado de apreensão da obra que enfoca a normatividade, quando exclusivo (aqui também não devemos ser exclusivistas ou unilaterais, como Mário advertirá no Ensaio), faz tabula rasa das nuanças e ambiguidades do texto - da sua polifonia e suas dissonâncias -, que talvez importem tanto ou mais (ao menos para nós, hoje) por permitir rediscuti-lo em outras e novas bases. Afinal, são suas ambiguidades que como que "sismografam" o curso do processso sócio-histórico e a elas também se deve o interesse contemporâneo que suas ideias ainda guardam. Não podemos esquecer que Mário, além de ser enfático sobre a necessidade de qualificar os variados "ismos" a ele atribuídos, ${ }^{2}$ e isso certamente valia também para o nacionalismo, declarou a Renato de Almeida "desprezo enorme pelos rótulos" - "pouco me interessa de ser uma coisa ou outra" (Nogueira, 2003) - e a Prudente de Moraes Neto: "De mim já se falou que sou futurista, que sou desvairista, que sou impressionista, que sou clássico e que sou romântico. É verdade que tenho sintomas e qualidades de tudo isso. Porêm é questão de fim de receita: Dissolve-se tudo isso no século vinte e agita-se. Que que dá? Dá moderno. Estou convencido que sou do meu tempo" (Andrade, I985: I 23). Reabrir a "caixa preta" do nacionalismo e da identidade nacional em Mário de Andrade, portanto, constitui ponto de partida para recuperar a perspectiva própria com a qual ele interagiu com as questões dominantes de seu contexto e desconstruir a imagem que dele a fortuna acabou por sedimentar, como principal ideólogo da identidade nacional e da cultura brasileira autêntica; reputação que não apenas datou como, em grande medida, limitou o alcance crítico e a acuidade de suas ideias, assimilando-as aos valores então hegemônicos e obliterando o Mário incompossível com seu tempo e com as contradições persistentes da vida social brasileira.

\section{MEDITAÇÃO SOBRE O BRASIL}

Como se sabe, o "epistolomaníaco" (cf. Moraes, 2007) Mário costumava compartilhar com os amigos os planos de confecção de seus livros. É desse modo, aliás, que temos notícias de muitos dos seus projetos não concretizados ou transformados ao longo do caminho. Em outubro de I923, por exemplo, anunciara a Renato de Almeida ter começado a escrever a sua História da Música, que prevê como "trabalho pensado, vivido e longo" e pergunta antecipadamente se aceitaria que o livro lhe fosse dedicado. O musicólogo maranhense que, radi- 
cado no Rio de Janeiro, integrava o grupo dos modernistas cariocas, por sua vez, também desde I 923 mantém o amigo paulista informado da finalização de sua própria História da música brasileira, só publicada em I926, mesmo ano em que Mário lhe remete dois capítulos já prontos de seu trabalho em preparação e conta que está escrevendo um "livrinho" ao qual tenciona "dar o maior caráter normativo possível, discutindo e comentando as nossas possibilidades nacionais rítmicas, melódicas harmônicas polifônicas instrumentais (sinfônicas) etc.", àquela altura intitulado "Diálogo sobre a música brasileira".

Em carta de 7 setembro de I926 para Manuel Bandeira, confirma sobre o mesmo "livrinho" - nomeado agora, porém, Bucólica sobre a música brasileira e escrito, segundo o missivista, em seis dias de uma ebulição intensíssima - que seria uma "artinha" na forma de diálogos entre professor e aluno, chamados por ele, respectivamente e a princípio, de Lusitano e Sebastião, e teria as seguintes partes: Preâmbulo; Introdução no assunto; Rítmica brasileira; Orquestração brasileira; Harmonização brasileira; Melódica brasileira; Elogio de Carlos Gomes; Continuação de Melódica brasileira; Conclusão do assunto e Final (Andrade, 2000: 306). A estrutura evidencia que a Bucólica tornar-se-ia a parte teórica do Ensaio.

Em relação ao título, vale fazer duas observações. A primeira é que, ao vestir a carapuça, por assim dizer, da crítica que Mário de Andrade faz à "falta de valor prático" da musicologia brasileira após a publicação de sua História da música brasileira, Renato de Almeida afirma que teria sido melhor intitulá-la, a fim de evitar incompreensões como essa, Ensaio sobre a música brasileira (título que ele havia originalmente escolhido). Não há indícios na correspondência de que, após a longa discussão que se travou, o título tenha sido ofertado ao amigo, o que nos deixa a especular se isso não teria ocorrido em um dos seus encontros pessoais. Pouco importa; fato é que Mário abandona o título que vinha considerando e adota esse. Ou quase esse, pois a segunda observação é que, devido a erro da editora e contrariando as determinações do autor, conforme assinala sua discípula Oneyda Alvarenga (I974: 69), o título do livro aparece com o artigo definido "a" anteposto ao substantivo música brasileira. Esse equívoco, aparentemente banal, constitui, no entanto, uma espécie de sintoma de uma ambiguidade subterrânea ao Ensaio - a "presença ausente" do artigo coloca em jogo justamente a possibilidade de definir, individualizar e modificar esse substantivo, cujo sentido, na ausência do artigo, é vago e indeterminado, mas que, não obstante, é adjetivado brasileira.

A continuidade entre esses projetos e o Ensaio é corroborada pela preocupação com o que chamou precariamente, àquela altura, de torneios melódicos (Andrade, 2000: 307-308; cf. Teixeira, 2007).

Você me pergunta duvidoso: "Quanto a torneios melódicos nacionais, haverá mesmo isso?" Certo que há. Porém se principio discutindo isso não acabo mais tanto o assunto é grande. Porém repare numa coisa: as músicas francesa, italiana 
e alemã não têm nenhuma rítmica particular, nem harmonização nem orquestração nem nada. No entanto se distinguem. Por onde? Primeiro pelo caráter psicológico, que é a coisa mais importante e é justamente o ponto por onde se discute a brasilidade de muita coisa que a gente exclui levianamente do patrimônio nacional. E depois? Se distingue pelo torneio melódico. Você perguntará: quais os torneios de cada uma? Segundo que não sei. Porque nunca me apliquei a esse estudo e ninguém não o fez ainda. Disso a culpa não é minha e me dificulta muito o meu trabalho. Porém algumas tendências mais freqüentes ou mais peculiares da nossa melódica já consegui distinguir. O que ainda não experimentei é se ajuntando todos eles num pasticho sem rítmica brasileira consigo fazer uma composição sem caráter brasileiro. Porque se conseguir prova não a inanidade desses caracteres, pois que eles existem e posso documentar isso com abundância porém prova que são muito vagos. Também vou ver se se pode criar música brasileira sem nenhum dado característico da gente (Andrade, 2000: 307-308).

A reflexão sobre esse conjunto de tendências e constâncias na criação poético-melódica teria sido disparada por uma reavaliação da música de Ernesto Nazaré, que, apesar de extraordinária, dizia o volúvel Mário de Andrade, carecia de caráter melódico brasileiro. A melodia antes considerada carioca e de influência portuguesa passava a ser vista como um pouco alemã e muito "sem caráter", como viria a ser definido o futuro protagonista "incaracterístico" de seu romance rapsódico. Por isso, diz a Bandeira, começa um estudo que deveria ser comparativo e de longuíssimo prazo ("durará minha vida"), indagando "quais são os torneios melódicos caracteristicamente (não exclusivamente se entende) brasileiros" (Andrade, 2000: 305). Característico, mas não exclusivo: assim, suscitado pelo próprio objeto, o método comparativo permitiria identificar "coincidências" - como aquelas entre as linhas melódicas de um rondó de Beethoven e "Bico de papagaio", de Abdon Milanez, discutidas na carta - que criariam uma sensação de semelhança entre diferentes músicas, como entre a brasileira e a russa (para ficarmos no exemplo da carta). Mas também seria complementado pelo experimento de transfigurar melodias europeias em brasileiras. A resposta de Bandeira indica adesão à hipótese de Mário:

Haverá creio, e tanto na melodia como nos outros elementos da música, ritmo, harmonização, timbres, andamentos, haverá preferências por certas formas, sem que nenhuma possa por si caracterizar a nacionalidade. O que a caracteriza é como você diz o caráter psicológico. Mas este resulta da soma e relação de todos os elementos da música - melodia, ritmo, etc. A distribuição e dosagem deles é que assinalam a nacionalidade quando ela existe musicalmente. (O que me surpreende no caso brasileiro é que literariamente, politicamente, sociologicamente e uma porção de outros mentes, mal nos distinguimos como nacionalidade; e no entretanto musicalmente temos nacionalidade marcante - falo, é claro, da música popular) (Andrade, 2000: 310).

Embora com o passar do tempo os "torneios" deixassem de integrar o léxico de Mário, as constâncias musicais continuariam na ordem do dia no Ensaio sobre música brasileira. Dividido em duas partes, a segunda reuniria uma 
coleção de 122 melodias populares inéditas destinada ao aproveitamento dos compositores. Vale lembrar, nesse sentido, que em fevereiro de I927, Mário dá notícia a Drummond de que estava preparando um "livro de folclore musical em que registrarei o maior número possível de melodias populares ou popularizadas nacionais, sempre com comentário" (Andrade, 2002: 279), Elementos melódicos nacionais, e lhe pede que obtenha melodias e esclarecimentos junto a músicos populares da sua região. Embora sua pesquisa de melodias populares viesse de longa data - desde o início da década de I920 - a coleta indireta, através de colaboradores, recebe impulso com o convite feito por Renato de Almeida, no início de I928, para colaborar no Congresso de Arte Popular de Praga, como se fica sabendo pela correspondência. A coleta direta também ganha fôlego com a viagem do turista aprendiz ao Norte em I927, onde estuda as festas populares do meio do ano. Intensifica-se então a "registração de melodias populares brasileiras", e as 50 melodias inéditas inicialmente coligidas avolumam-se muito em pouco tempo. Devido a exigências imprecisas do comitê organizador, Mário acaba desistindo de colaborar no congresso. ${ }^{3} \mathrm{E}$ o trabalho realizado, originalmente "coisa pra estranhos", precisaria "ser refundido para servir pro Brasil". Por esses ramais traça-se o caminho, para jogar com a bela expressão de livro pioneiro de Telê Ancona Lopez (1972) sobre Mário de Andrade, que desembocaria no Ensaio.

O Ensaio sobre música brasileira ganha inteligibilidade em um contexto de transformações da linguagem musical que produziram a expansão da dissonância e a erosão da tonalidade fixada e da ordem (social, política e cultural) que ela representa (Schorske, I988). As rupturas que levaram ao descentramento do paradigma da música ocidental tiveram na valorização das músicas de culturas "primitivas", "tradicionais" e não ocidentais uma de suas principais fontes. Exemplo emblemático é o encontro de Debussy com a orquestra de gamelão javanesa, seu sistema tonal não diatônico e seu modelo significativo de complexidade rítmica. Para Debussy, a música do Leste representou uma alternativa ao romantismo wagneriano e ao cromatismo. Em obras como "Prélude à l'après-midi d'un faune", células melódicas curtas e o uso da escala de tom inteiro substituíram a necessidade de um centro tonal, e procedimentos polimétricos e polirrítmicos suplantaram o sentido tradicional de tempo e ritmo.

O chamado primitivismo estético, que atraía o interesse das vanguardas artísticas europeias como meio de revitalização de uma longa tradição estética considerada decadente, no caso do modernismo brasileiro habitava não em lugares distantes e exóticos, mas em nossa sensibilidade, o que abria uma produtiva frente de exploração das afinidades entre o "primitivo"e o "popular" no Brasil. O primitivismo constituiu mesmo um ponto de passagem entre a Europa e as culturas não europeias. Se esse interesse pelo "primitivo" não explica inteiramente o programa de abrasileiramento do Brasil de nossos modernistas, em particular o de Mário de Andrade, é preciso reconhecer que facilitou 
muito a valorização de nosso passado e nossas manifestações artísticas populares e eruditas, até então vistas com preconceito e desconfiança, como se não passassem de expressão de nosso atraso ou inferioridade em relação à arte europeia (Botelho, 20I 2). Assim, nos anos I930, as formas culturais "primitivas" e populares serão convertidas em símbolos do "nacional", como se fossem reflexos de uma identidade previamente constituída e não cristalizações de intrincadas negociações de diferenças culturais. De selvagem, sensual e perigoso, traços que justificavam até então sua proscrição, o primitivo seria transformado em signo do moderno nos trópicos (Garramuño, 2009), bastando assinalar o "milagre" da transubstanciação da mestiçagem - de mácula em nossa redençãoe todos os esquecimentos e silêncios que ele implica.

Observa-se o fortalecimento da cultura popular urbana naquele período, mas também a imposição, em âmbito internacional, de uma agenda de nacionalização das linguagens artísticas com base na cultura popular ou primitiva, o que alinhava o modernismo musical no Brasil às vanguardas internacionais na busca de novas sonoridades, diretamente associada à fragmentação do sistema tonal. Ou seja, o uso de códigos nacionais na criação artística não era idiossincrático. O resgate da herança do folclore musical, nos termos propostos no Ensaio, se não tinha o ímpeto iconoclasta propagado na Semana de I922, não deixava de ser "moderno" - apesar de manter relação tensa com a "tradição" - e operar, como aponta Contier (I995), como um "contradiscurso revolucionário", ao romper com os padrões estéticos passadistas e combater o gosto musical e os preconceitos das elites burguesas orientadas pelos ideais europeus de civilização e progresso. Além de colocar em xeque as escutas tradicionais das elites, o novo discurso sobre a cultura brasileira que se procurava instaurar visava corrigir a distância social entre o erudito e o popular (Hamilton-Tyrrel, 2005). Era, portanto, não apenas cosmopolita como progressista no quadro de uma sociedade elitista e europeizada, embora a visão de Mário não fosse ingênua a ponto de acreditar que a cultura popular e a sociedade brasileira fossem em si mesmas virtuosas. No entanto, por uma "dupla hermenêutica" complexa - na qual importa menos a intenção do que o efeito e a apropriação - o que era contradiscurso subversivo na década de I 920 acabaria, à revelia do autor, "aproximando-se historicamente da construção do mito da nacionalidade, fundamentado no folclore, durante o getulismo" (Contier, 2010: 92). Desse modo, o Estado Novo seria responsável por forjar uma imagem monocórdica do modernista arlequinal, como construtor da Cultura Brasileira (com maiúsculas), e Mário, por vias impremeditadas, acabaria "refém" de seu próprio projeto. Assim, sugerimos que o sentido e o significado de "nacionalismo" e "identidade nacional" do Ensaio se veem refratados e oclusos pelo sentido político que o processo social acabaria assumindo e as ideias de Mário, disciplinadas pelo paradigma então dominante da unidade nacional. O ponto que enfatizo, porém, diz respeito à hipótese de que a valorização da cultura e das práticas populares, 
no caso de Mário de Andrade, não se esgota numa preocupação ontológica (em verdade presente, mas incapaz de conferir sentido geral a sua obra), redutível ao nível programático-apologético de seu tão glosado nacionalismo. Sua obsessão pela cultura popular seria mais a expressão do dilaceramento e da percepção da sociedade "em suas tensões sísmicas não aparentes do que de um feliz arranjo de classes e raças que se acomodariam harmonicamente para sanar a falta de 'caráter' nacional”, como sugere José Miguel Wisnik (I979: 46). Se Mário valorizou o saber que existe na expressão cultural dos descendentes de grupos étnicos que foram dizimados ou explorados e esquecidos pela elite europeizada e escravista do país, ou buscou aproximar criticamente erudito e popular, ou mesmo trespassar de maneira iconoclasta suas fronteiras, o interesse dessa sua contribuição vai além das nas manifestações que colheu ou colecionou, ressoando no reconhecimento que provocou delas e de seus portadores sociais em suas dignidade e alteridade plenas como parte de um projeto de nação, o que numa sociedade tão desigual e pouco democrática como a brasileira mesmo hoje está longe de ser trivial.

Logo no início do Ensaio Mário formula sua potente crítica - que dará a tônica na economia interna dos argumentos - ao que denomina exotismo (e que rebate os pressupostos do próprio eurocentrismo), o qual levaria internamente à defesa do pitoresco e externamente à orientação pelos modelos e valores da civilização europeia. Assim, alega que os modernos, ciosos da curiosidade exterior de muitos dos nossos documentos populares, defendem "o jamais escutado em música artística, sensações fortes, vatapá, jacaré, vitória-régia” (Andrade, I972: I4). O exotismo, porém, articula-se também para fora, por meio do que chama de opinião de europeu: "o diletantismo que pede música só nossa está fortificado pelo que é bem nosso e consegue o aplauso estrangeiro" (Andrade, I972: I4). Já se percebe aí que o autor mobiliza a ideia de que as culturas não são autocontidas, mas estão em relação, desigual no caso, entre si. Com a ironia fina que lhe é característica, Mário afirma que um "coeficiente guassú" de exotismo teria concorrido para o sucesso de Villa-Lobos na Europa - lança mão, portanto, de uma exótica palavra tupi-guarani para criticar a própria ideia de exotismo. Prossegue argumentando que

A Europa completada e organizada num estádio de civilização, campeia elementos estranhos para se libertar de si mesma. Como a gente não tem grandeza social nenhuma que nos imponha ao Velho Mundo, nem filosófica que nem a Ásia, nem econômica que nem a América do Norte, o que a Europa tira da gente são elementos de exposição universal: exotismo divertido. Na música, mesmo os europeus que visitam a gente perseveram nessa procura do esquisito apimentado. Se escutam um batuque brabo muito que bem, estão gozando, porém se é modinha sem síncopa ou certas efusões líricas dos tanguinhos de Marcelo Tupinambá, Isso é musica italiana! Falam de cara enjoada. E os que são sabidos se metem criticando e aconselhando, o que é perigo vasto. Numa toada, num acalanto, num abôio desentocam a cada passo frases francesas, russas, escandinavas. Às vezes especificam que é Rossini, que é Boris. Ora, o quê que tem a Musi- 
ca Brasileira com isso! Se Milk parece com Milch, as palavras deixam de ser uma inglesa outra alemã? O que a gente pode mais é constatar que ambas vieram dum tronco só. Ninguém não lembra de atacar a italianidade de Rossini porque tal frase dele coincide com outra da ópera-cômica francesa (Andrade, I972: I4-I5).

Como se vê, o modernista entende que nos processos socioculturais estruturas e formas podem combinar-se para gerar algo novo, o que já coloca em suspeita qualquer pretensão de definir identidades "puras" ou "autênticas", uma vez que elas são sempre abstrações da história das misturas em que se formaram e dos conflitos que as construíram - a cultura não seria, nessa concepção, uma unidade expressiva e homogênea, campo do consenso e da reconciliação. No entanto, Mário também está atento ao fato de que, se se estabelecem fluxos e trocas interculturais, o mesmo não implica integração ou fusão harmoniosa, mas contradições e, sobretudo, assimetria. Economia política e cultura articulam-se - não é como se as desigualdades econômicas fossem não culturais ou as diferenças culturais fossem imateriais ou apolíticas. Antes, as diferenças culturais estão estreitamente ligadas a questões de desigualdade, aspiração e posição em um mundo imaginado (Ferguson, 2006). Como escreverá anos mais tarde, na "balança universal", "a permanência das artes de um determinado país na atenção do mundo, está na razão direta da importância político-econômica desse país" (Andrade, I972: 33). Para Mário, é quase como se pudéssemos falar em uma divisão internacional do trabalho artístico, que nos subordina a fornecer a matéria-prima exótica que a Europa demanda para se libertar dos grilhões de sua tradição decadente e se renovar. A prosa raciocinante de Mário vai operar no nível de naturalização dos pressupostos culturais e das relações sociais. Não importa o quanto a Europa importasse exotismo permaneceria "pura", já a cultura brasileira "autêntica" não poderia imitá-la, sob pena de se deixar contaminar por elementos exógenos. Para o autor, contudo, não haveria uma cultura brasileira nacional anterior e exterior à cultura ocidental - e essa, note-se, é uma visão até antinacionalista. Ela é parte da cena contemporânea. Se a importação cultural produz distorções significativas, a cópia é inevitável, e é justamente no deslocamento provocado por ela - e na reelaboração suscitada pelas contradições locais do processo histórico - que residiria a particularidade da cultura brasileira. Nesse espaço complexo entre a assimilação a um modelo original e a necessidade constante e incansável (e possivelmente inalcançável) de reelaboração, interessam os tensionamentos das visões estáveis e polarizadas de identidade, as múltiplas variações de significado a partir de um mesmo e aparentemente cristalizado significante.

Outro vetor da crítica do autor ao exotismo incide na defesa de nossos traços ameríndios como distintivos do "caráter nacional". Mário não só prontamente recusa e ironiza essa postura como fetiche de autenticidade, mas tece comentário que faria a delícia de antropólogos nossos contemporâneos: “O homem da nação Brasil hoje, está mais afastado do ameríndio que do japonês 
e do húngaro. O elemento ameríndio no populário brasileiro está psicologicamente assimilado e praticamente já é quasi nulo. Brasil é uma nação com normas sociais, elementos raciais e limites geográficos. $\mathrm{O}$ ameríndio não participa dessas coisas e mesmo parando em nossa terra continua ameríndio e não brasileiro. O que evidentemente não destrói nenhum dos nossos deveres para com ele" (Andrade, I 972: 33). Ora, frise-se, o modernista indica, em I 928, que o ameríndio não se reconhece como membro da comunidade política nacional, mas como índio, o que, porém, não dispensa o Estado de lhe reconhecer seus direitos. No que diz respeito ao "caráter nacional", recorremos a uma carta a Luciano Gallet de 25 de agosto de i926:

Inda o Lourenço Fernandes escutei dizer que a Alma Brasileira, Choros no.5 do Villa, tinha no meio uma marcha que não tinha caráter brasileiro... Isso é pueril. O que é caráter brasileiro? Por acaso o caipira que nunca saiu do rancho dele lá numa vila esquecida do sertão é que só ele é brasileiro e não o indivíduo que mora em S. Paulo ou no Rio e sai de forde de casa e recebe revistas alemãs? Isso tudo são puerilidades porque em todos os caracteres raciais nacionais tem uma parte muito larga de cooperação universal. Se a gente analisar uma obra de arte bem francesa há de encontrar nela muito de alemão muito de italiano e muito de toda a gente (Andrade apud Lisbôa, 2015: 59).

Vale citar ainda outro trecho do raciocínio perspicaz e não menos irônico de Mário sobre o exotismo, que relativiza, desnuda e coloca em xeque o preconceito da posição que o defende: "Se fosse nacional só o que é ameríndio, também os italianos não podiam empregar o órgão que é egípcio, o violino que é árabe, o cantochão que é grecoebraico, a polifonia que é nórdica, anglo-saxônica flamenga e o diabo. Os franceses não podiam usar a ópera que é italiana e muito menos a forma-de-sonata que é alemã. E como todos os povos da Europa são produto de migrações pré-históricas se conclui que não existe arte europeia..." (Andrade, I972: I6). Pode-se dizer que esse raciocínio - ao demonstrar o infundado de hierarquias como a de que a "cópia" é secundária em relação ao "original", depende dele, vale menos etc. - conduz ao próprio questionamento do primado da origem que jaz como pressuposto de noções de cultura ou identidade autênticas. Não obstante o alívio que a solução pudesse proporcionar ao amor-próprio e também à inquietação de um país assolado por uma epidemia de "moléstia de Nabuco" - que fazia nossas elites sentirem saudades do cais do Sena em plena Quinta da Boa Vista -, Mário, como se vê, não cai na ilusão simplória e inversa de supor que a não reprodução da tendência europeia, já desvestida de seu prestígio de originalidade, poderia nos dar uma vida intelectual, artística, social etc. mais substantiva, com um fundo nacional genuíno, não adulterado.4 "Música Brasileira deve significar toda música nacional como criação quer tenha quer não tenha caracter étnico", diz o autor atentando para o caráter recente das "escolas étnicas" em música, diretamente associadas à formação histórica dos Estados-nações, forma de insti- 
tucionalidade política moderna que não serve de marcação temporal ou simbólica estável para, ou à qual não se subsume, a ideia de nacional com que ele opera. Como observa,

Ninguem não lembra de tirar do patrimônio itálico Gregorio Magno, Marchetto, João Gabrieli ou Palestrina. São alemães J. S. Bach, Haendel e Mozart, três espíritos perfeitamente universais como formação e até como caracter de obra os dois últimos. A França então se apropria de Lulli, Gretry, Meyerbeer, Cesar Franck, Honnegger e até Gluck que nem franceses são. Na obra de José Maurício e mais fortemente na de Carlos Gomes, Levy, Glauco Velasquez, Miguez, a gente percebe um não-sei-quê indefinível, um ruim que não é ruim propriamente, é um ruim exquisito pra me utilizar duma frase de Manuel Bandeira. Esse não-sei-quê vago mas geral é uma primeira fatalidade da raça badalando longe (Andrade, 1972: 17).

A perspectiva de Mário está imbuída de um agudo senso das contingências, que incide, aliás, sobre a inteligibilidade do caráter interessado ou normativo de seu nacionalismo instrumental: "se tratava de estabelecer um critério geral e transcendente se referindo à entidade evolutiva brasileira. Mas um critério assim é ineficaz pra julgar qualquer momento histórico. Porque transcende dele. E porque as tendências históricas é que dão a forma que as ideias normativas revestem" (Andrade, I972: 20, grifos nossos). O modernista parece sempre consciente da historicidade do programa nacionalista proposto: sua concepção de música brasileira não é substantiva, mas "estabelecida" visando a um fim, nem a-histórica - não se aplica a todo e qualquer momento histórico -, mas suscitada por condições históricas particulares. O nacionalismo seria, então, "preconceito útil" para se atingir liberdade de criação que teria uma finalidade cosmopolita. E a afirmação da cultura popular, no singular, seria condição para o reconhecimento das culturas populares, no plural. Assim, "o critério de música brasileira prá atualidade deve existir em relação à atualidade" apenas e "sem nenhuma xenofobia nem imperialismo", acrescenta (Andrade, I972: 20). Vale a pena recorrer a uma longa passagem extraída de artigo publicado na série "O mês modernista" organizada pelo próprio Mário no jornal A Noite, em que esse ponto ganha destaque, bem como sua visão plural de mundo, sensível não apenas às diferenças, mas também à correlação desigual de forças sócio-históricas que lhe disputam o sentido.

Na verdade o que a gente chama de "atualidade" embora possa tomar seus elementos e manifestar as tendências em todos os países do mundo, (coisa muitíssimo discutível e provavelmente falsa), a tal de "atualidade" é a cousa mais relativa, mais hipotética, mais falsa mesmo que existe, se a gente considera sob o ponto-de-vista universal. Não existe uma atualidade universal. Existe mas é uma atualidade duma região mais ou menos vasta, que é imposta ao mundo por causa da função histórica de interesse universal que essa região está representando no momento da humanidade. E por isso a 'atualidade' dessa região ecoa por toda a parte, quer pela influência da moda; quer pela simples macaqueação pastichadora; quer pela eficiência ou possibilidade de progresso que esta atualidade estranha pode trazer pra outro país. 
Além dessa atualidade representativa do momento histórico mais ou menos universal, mas que de fato é regional, existe um despropósito de atualidades. Cada país já principia por ter a dele. A atualidade do Brasil não é a mesma da China, está claro. Porém, dentro de cada país mesmo além de uma atualidade nacional definida principalmente pela economia, pela política, pela cultura nacional, existem várias atualidades. Mesmo sob o ponto de vista exclusivamente artístico cada classe social tem a dela. [...]

Dentro do Brasil também a atualidade representativa do momento histórico universal, nos veio da Europa (via França e Itália) e dos Estados Unidos. Essa atualidade tinha aqui uma possibilidade vasta de funcionar em proveito do país. E funcionou de fato. [...]

E o maior benefício que a atualidade estranha trouxe pra gente foi, não coincidindo com o regionalismo e o nacionalismo que já existiam por aqui, levar pela liberdade pela procura do novo e da realidade nacional, que se levou os modernistas a maturar sobre o dualismo do fenômeno universal-nacional. Resultou, foi uma consciência mais imediata, mais livre da realidade nacional, que aí levou uns pobres pra patriotada artística, se está produzindo muita arvinha reles, muito cambuci etc. generalizou no sufragante a consciência artística nacional e levou toda a gente quase pro trabalho de fazer coincidir a realidade individual com a entidade nacional. Esta coincidência quando estiver normalizada e inconsciente em nós, dará pros artistas brasileiros a mais justa, a mais fecunda e nobre libertação.

E como este problema de acomodar a invenção artística nossa com a entidade nacional, era importante por demais, ele evitou que a "atualidade" histórica universal que nos vinha de França e de outros países da Europa, continuasse aqui como simples reflexo, simples macaqueação. Dum momento pra outro a inquietude europea (produto de excesso de cultura, produto de esfalfamento, produto de decadência) não coincidiu mais com a inquietude brasileira (produto de problemas nacionais ingentes, produto de progresso, produto de terra e civilização moças, principiando apenas). Com efeito as capelas artísticas europeas deixaram de repente de influir na criação brasileira. Nos interessa agora como curiosidade. Não tem mais pra nós uma importância funcional. Ninguém mais entre os espíritos já formados, se amola de estar no dernier-bateau parisiense ou florentino. Se volta ao metro como se foge dele, se pinta palmeiras como se esculpe banhistas, sem mais a preocupação da atualidade europeia. Porque já readquirimos o direito da nossa atualidade (Batista, Lopez \& Lima, I972).

Segundo Mário, seria preciso reconhecer a diversidade de matrizes étnicas da música brasileira, eminentemente híbrida: ameríndia (em porcentagem pequena), africana, portuguesa, a influência espanhola (sobretudo a hispano-americana do Atlântico - Cuba e Montevidéu, habanera e tango) e a europeia, pelas danças (valsa, polca, mazurca) e na formação da modinha. Se o artista deveria selecionar a documentação que lhe serviria de estudo ou de base, por outro lado não deveria cair num "exclusivismo reacionário que é pelo menos inútil” (Andrade, I972: 26). Mário propõe que "a reação contra o que é estrangeiro deve ser feita espertalhonamente pela deformação e adaptação dele. Não pela repulsa" (Andrade, I972: 26). ${ }^{5}$ Se seria "preconceito útil" preferir o que já 
é caracteristicamente brasileiro, seria "preconceito prejudicial repudiar como estrangeiro o documento não apresentando um grau objetivamente reconhecível de brasilidade" (Andrade, I972: 26). Como comenta sobre as origens do fado, o que "realiza, justifica e define uma criação nacional folclórica é a sua adaptação pelo povo", e não o seu "registro de nascença" (Andrade, I976b: 95). Ora, o elemento estrangeiro é constitutivo da própria brasilidade, que se origina de uma espécie de bricolagem, ou do "afeiçoamento", de experiências socioculturais diversas. Nessa concepção de identidade aberta e inacabada, a brasilidade é porosa e descentrada, implicando não o que denomina excessivo característico "exterior e objetivo", mas um compósito indefinível que ele chama aí algo obscuramente de "psicológico" (Andrade, I972: 27). Por outro lado, Mário pondera que o excessivo característico pode ser útil para "determinar e normalizar" os caracteres étnicos da musicalidade brasileira, contanto que não transformado em norma única de criação e crítica e, assim, em atrativo de exposição universal. Nesse ponto, portanto, Mário é sintomaticamente ambíguo em relação à necessidade de diferenciação do nacional - mantendo-o porém indefinível porque apenas "psicológico" - e aos perigos de homogeneização que isso inevitavelmente acarreta. Quanto ao artista, não deve ser nem "exclusivista", nem "unilateral", mas cultivar a diversidade e a diferença, e delas se beneficiar. Desse modo, a cópia diferida do modelo poderia engendrar uma música original. Mas originalidade, está claro, não equivale à pureza e/ou à autenticidade; ao contrário, envolve o relacionamento sincrético com elementos estrangeiros. Nessa perspectiva desprovincianizante e não triunfalista que recusa a dualidade sem porém buscar transcendê-la ou superá-la numa síntese (divergindo frontalmente da visão predatória da antropofagia), as identidades não seriam inteiriças e fechadas em si mesmas, mas dinâmicas, uma vez que novos elementos podem ser incorporados - pelo diálogo e não pela deglutição -, possibilidade suscitada naquele contexto pela disseminação do jazz e do tango, como anota o autor.

No contexto dos anos I920-I940, a questão da influência da cultura portuguesa na formação nacional será um dos principais vezos do debate contemporâneo sobre a circulação e o deslocamento das ideias/formas/instituições e sua recepção, aclimatação, adaptação ou não, bem como seus usos e apropriações em outra realidade social. Exemplos disso são ensaios como Raízes do Brasil (I936) e Casa-grande \& senzala (I933). No Ensaio, circunscrita aos perigos do exclusivismo e da unilateralidade, aparece a preocupação de Mário com a "reação contra Portugal", que não levaria em conta que é pela "ponte lusitana que a nossa musicalidade se tradicionaliza e justifica na cultura europeia" (Andrade, I972: 28). Essa preocupação receberia desenvolvimento no estudo "Influência portuguesa nas rodas infantis do Brasil”, elaborado no mesmo período como memória para o Congresso Internacional de Arte Popular, de Praga ${ }^{6}$, no qual investiga os processos de adaptação, deformação e transformação de ele- 
mentos musicais e literários de canções portuguesas, isto é, importados. Observa que a influência não é de mão única, estabelecendo-se um sistema de intercâmbios e remodelações intrincado, no qual se trocam textos e melodias; agregam-se vários textos ou várias melodias; estes são fracionados; inventam-se melodias novas para textos tradicionais.

Escrito em I926 e publicado em I928, Macunaíma poderia ser lido na chave aqui proposta quase como um díptico do Ensaio, transpondo criticamente para a literatura o conflito divisado na música entre a tradição europeia herdada de Portugal e as manifestações locais. Concebida a partir da bricolagem de uma infinidade de materiais - elaborados pelas tradições oral ou escrita, popular ou erudita, brasileira, europeia, africana ou indígena -, a obra maior de Mário de Andrade submete esse material de múltipla procedência a toda sorte de mascaramentos, transformações, deformações e adaptações (talvez também por essa razão, entre outras, o livro acabaria associado à vertente antropofágica do modernismo, a contragosto de seu autor). Embora aparentemente parasitário, esse mecanismo combinatório é, contudo, inventivo, pois, em vez de destacar com neutralidade nos entrechos originais as partes de que necessita para as recompor, inalteradas, num novo arranjo, age quase sempre sobre cada fragmento, transformando-o profundamente. Assim, Macunaíma como que formaliza, em sua própria fatura, o caráter híbrido da cultura e plural da identidade brasileira, bem como questiona a ideia de pureza, ao produzir um texto original quase inteiramente a partir da cópia e da deformação. De acordo com interpretação fundamental de Gilda de Mello e Souza (2003), porém, mais do que na técnica do mosaico ou no exercício da bricolagem, o modelo compositivo desse "romance rapsódico" (como passaria a ser designado a partir da segunda edição) é ele mesmo copiado do processo criador da música popular, por meio da transposição de duas formas básicas que são ao mesmo tempo normas universais de compor: a suíte e a variação (Mello e Souza, 2003; Andrade, I972: 66-69). Nesse sentido, o processo de Macunaíma parece fundado diretamente em dois exemplos precisos do populário brasileiro: a canção de roda e o improviso do cantador nordestino. Da primeira extrai o mecanismo de agrupar numa mesma ordem textos muito diversos; de projetar num texto tradicional um sentido recente; ou, ainda, de conservar basicamente um entrecho original, modificando essencialmente todos os detalhes. Em relação ao segundo, o próprio Mário de Andrade (I976a: 433-435) confessa em carta pública a Raimundo Moraes que construiu o livro baseado na cópia, no plágio, na transcrição de trechos alheios - enfim, nos processos dos cantadores do Nordeste e dos rapsodos de todos os tempos. Espécie de alegoria sobre a identidade nacional, essa composição rapsódica projetaria ambiguidade em todos os níveis da narrativa (evocando tanto a inquietação da linha melódica identificada como constância do populário no Ensaio quanto a possibilidade de criação de uma melodia infinita caracteristicamente nacional). Do entrecho, cuja linha principal - a perda e a busca da muiraquitã 
(ou, bem se poderia dizer, da identidade) - se veria eclipsada permanentemente pela multiplicação incessante dos episódios acessórios, estender-se-ia, na "embrulhada" cronológica e geográfica, até a caracterização do cenário e das personagens e suas ações, aí incluído o protagonista, que costuma ser interpretado, à revelia do autor, como símbolo do brasileiro. Assim, porque os diferentes sentidos comunicados por essa "alegoria" não se resolvem necessariamente numa síntese, o heterogêneo e o inacabamento são convertidos em elementos expressivos da estrutura, dando vazão à própria visão descentrada e aberta de identidade de Mário. Do ponto de vista cultural, Macunaíma, como a sociedade brasileira, também oscilava entre a falta e o excesso e se encontrava dilacerado entre ordens sociais e valores contrastantes que nunca se resolvem: o tradicional e o moderno, o rural e o urbano, o Brasil e a Europa. Não podemos esquecer ainda que o próprio autor afirma que o herói "sem nenhum caráter" de nossa gente foi tirado do alemão Koch-Grünberg, caracterizando-o "incaracteristicamente" como um índio preto que vira branco e que nem brasileiro é, pois faz parte do lendário da Amazônia venezuelana, o que lhe permite a um só tempo figurar a busca da identidade nacional e problematizar crítica e ironicamente essa intenção que certamente era coletiva e de várias épocas.

Desse modo, Macunaíma (e por tabela o Ensaio) representava um percurso atormentado, feito de muitas dúvidas e poucas certezas sobre o povo e o país; evidenciava, em vários níveis, da linguagem à cultura, "a preocupação com a diferença brasileira; mas, sobretudo, desentranhava dos processos de composição do populário um modelo coletivo sobre o qual erigia a sua admirável obra erudita" (Mello e Souza, 2003: 29). Em outras palavras, Mário realizava na literatura, com Macunaíma, o que propunha aos músicos, no Ensaio sobre música brasileira. Entende-se assim o papel que o modernista reserva aos compositores no aproveitamento criativo e artístico da riqueza de possibilidades do populário.

Voltando ao Ensaio, essa mesma ressignificação do elemento europeu pode ser vista quando Mário discute a instrumentação, no exemplo da "orquestrinha". Nela o fato de a maioria dos instrumentos ser importada não impede que tenha assumido, até como solista, caráter nacional. Mário relata que, numa fazenda de zona que permaneceu especificamente caipira, teve oportunidade de escutar uma "orquestrinha" de instrumentos feitos pelos próprios colonos. "Dominavam no solo um violino e um violoncelo... bem nacionais. Eram instrumentos toscos não tem dúvida mas possuindo uma timbração curiosa meia nasal meia rachada, cujo caracter é fisiologicamente brasileiro" (Andrade, I972: 55). Timbre anasalado emoliente, de rachado discreto, longe do "efeito tenorista italiano ou da fatalidade prosódica do francês". No entanto, "é perfeitamente ridículo a gente chamar essa peculiaridade da voz nacional, de falsa, de feia, só porque não concorda com a claridade tradicional da timbração européia". Afinal, 
Ser diferente não implica feiura. Tanto mais que o desenvolvimento artístico disso pelo cultivo pode fazer maravilhas. Da lira de 4 cordas dos rapsodos primitivos a Grécia fez as I5 cordas da citara. Do santir oriental e do cimbalon húngaro que Lenau inda cantou, ao piano de agora, que distância através de todas as variantes de clavicórdios! Da escureza e dos erres arranhentos da fala dele o francês criou uma escola de canto magnífica (Andrade, 1972: 55).

Não se tratava de advogar "regionalismos curtos" nem de permanecer "embebedados pela cultura europeia", mas de perceber que os elementos nacionais sedimentados poderiam enriquecer-se pelo contato com o estrangeiro. Nesse movimento, Mário concede direito à diferença e valoriza uma certa capacidade de diferenciar sem hierarquizar. As hierarquias que decerto existem e vincam a vida social devem ser detectadas pelo olhar, mas não por ele projetadas. Além disso, rejeita uma visão historicista do tempo, em que este seria percebido como um processo linear, evolutivo e progressivo, articulando eventos numa lógica de causa e consequência, e a realidade por sua vez passaria a ser vista como uma totalidade coerente e ordenada.

O ritmo seria, segundo Mário, um dos principais parâmetros a provar a riqueza e complexidade da música popular. Certas peças teriam rítmica tão sutil, diz o autor, que se torna praticamente impossível grafar em partitura "toda a realidade dela" (ver Hoelz, 20I5a). E tal fato se poderia comprovar na segunda parte do livro, em que nosso autor multiplicado, investido da máscara de musicólogo, faz uma cartografia musical do Brasil, apresentando peças colhidas em todos os cantos e algumas de suas variações. Essa aquarela sonora do Brasil, de caráter seminal, adquire naquele contexto o sentido de "desgeograficar" (Lopez, I972 e I976), por assim dizer, não apenas o espaço físico, amalgamando as diferentes regiões, mas também o espaço social e simbólico em sua complexidade, aproximando as gentes, as práticas culturais, a língua escrita da falada, o erudito do popular, a imaginação do sentimento brasileiro, o brasileiro do Brasil. O que poderia gerar tanto a ampliação de nosso campo cognitivo quanto formas mais plurais e inclusivas de identidades. Essa segunda parte do Ensaio nos daria ainda, segundo o autor, duas "lições macotas: o caráter nacional generalizado e a destruição do preconceito da síncopa” (Andrade, I972: 23).

Da ideia de "caráter nacional" já tratamos e a ela ainda voltaremos adiante. Em relação ao preconceito da síncopa, a ênfase do autor incide no fato de que essa figura é uma constância da música brasileira, mas não uma obrigatoriedade - observam-se, aliás, síncopas que não são brasileiras -, e que seu conceito tradicional que encontramos nos dicionários e artinhas, embora correto, por vezes não corresponde aos movimentos mais variados e livres da rítmica brasileira. Esta constituiria o produto histórico da fusão "transatlântica" da rítmica organizada e quadrada que Portugal trouxe da civilização europeia para os trópicos e da rítmica oratória desprovida de valores de tempo musical, dos ameríndios e africanos (Andrade, I972: 30). "A essas influências díspares e 
a esse conflito inda aparente o brasileiro se acomodou, fazendo disso um elemento de expressão musical" (Andrade, I972: 32). Assim, retomando o que desenvolvi em outro lugar (Hoelz, 20I5b), pode-se dizer que para Mário a solução do problema rítmico na música popular brasileira figura de certo modo a tensão dilemática da nossa formação social, aquele "sentimento dos contrários" que marca a dinâmica específica da experiência cultural num país colonial como o Brasil, tão bem sintetizado por Antonio Candido (I980: 4, 9) como uma dialética rarefeita entre localismo e cosmopolitismo, entre o não ser e o ser outro: "o brasileiro não pode deixar de viver pendurado no Ocidente e ele deve tentar não viver pendurado no Ocidente. Ele tem que tentar fazer uma cultura dele, mas a cultura que ele pode fazer é uma cultura pendurada no Ocidente [...] Nós somos o outro e o outro é necessário para a identidade do mesmo". "Daí a imundície de contrastes que somos", diz Mário (Andrade, I974: 8), a qual nos impossibilitaria de "compreender a alma-brasil por síntese". Em outras palavras, os ritmos populares como que cifram as contradições culturais do processo de colonização, engendrado no conflito entre os tempos divergentes da música europeia - o tempo da mensuração, do compasso, do ritmo demarcado pelos retornos regulares, em suma, da periodicidade quadrada - e da música indígena-africana - o tempo de uma rítmica fraseológica, prosódica, caracterizada pela expansão em aberto e por uma periodicidade continuamente variada. A música indígena e negra se caracteriza não pela subdivisão do compasso, mas pela adição de tempos - tempo afirmativo, que se realimenta na variação. Segundo Mário, a rítmica musical brasileira traduz e codifica essa nossa dualidade constitutiva, ao criar um "jeito fantasista de ritmar" que, produzindo "um compromisso sutil entre o recitativo e o canto estrófico", vai dançando as palavras livre e variadamente por entre as barras do compasso.

A síncopa europeia é uma consequência prática das especulações obtusas dos franco-flamengos e madrigalistas. Na América o conceito de síncopa surgiu doutra necessidade que por mais fisiológica e popular, se poderá chamar de mais essencial. [...] Na América a síncopa não provém da síncopa européia. É uma realização imediata e espontânea das nossas maneiras de dançar, mais sensuais, provinda do clima talvez, e do amolecimento fisiológico das raças que se caldearam pra nos formar e formaram também o remeleixo, o requebro, o dengue. É o movimento dengoso do corpo na dança que deformou a rítmica da polca primeiramente na rítmica da habanera e em seguida no do maxixe (Andrade, I989: 476).

A não submissão do ritmo à regularidade do compasso constitui justamente, nas danças coreográficas, a força dinamogênica que, ao empurrar os sons da linha pra fora do tempo batido, sugestionam o corpo a remelexos e dengues. Naturalmente, Mário surpreendia na síncopa uma potência se não subversiva, ao menos neutralizadora, da métrica regular do compasso. Como uma espécie de dobra ou espaço que medeia entre dois tempos, a síncopa se revela metafórica e musicalmente na transformação da polca em maxixe, por 
meio dos deslocamentos rítmicos - com a decantação da própria síncopa e seus efeitos contramétricos e balançantes - enlaçados à africanização abrasileirada desse exemplar de dança europeia (portanto, importada) de salão, sincreticamente misturada à música negra dos escravos (Wisnik, 2003). O abrasileiramento operado na sincopação da polca - pela acentuação em pontos deslocados do tempo, fora dos lugares tônicos do compasso binário, fixados originariamente no padrão importado (ou em pontos não tônicos da métrica regular do compasso) - produz um efeito oscilante entre dois pulsos simultâneos e defasados. O conceito de síncope aparece então como descompasso entre a partitura, feita para formalizar a harmonia, e uma polirritmia que a ela não se subordina sem deixar um resto. Trata-se, como sugere Wisnik (2003: 36), de uma dialética rítmica que se baseia no balanceio entre uma ordem e sua contraordem acentual, sustentadas num mesmo movimento, e que desencadeia um "negaceio estrutural [...], cheio de acenos e recuos, de promessas em aberto, de objetos chamativos e escapadiços, conduzidos numa cadência aliciante". Desse modo, Mário evita definir esses processos rítmicos a partir do ponto de vista unilateral da música europeia, reduzindo-os a desvios da norma do compasso; antes, sua lógica rítmica é eminentemente ambivalente, não se confinando à medida regular do compasso, baseada na subdivisão e replicação de células regulares. A rítmica brasileira seria - parodiando título célebre no debate sobre a aclimatação das ideias - "nacional por adição", isto é, procederia por meio da adição simultânea de células desiguais, pares e ímpares, produzindo múltiplas referências de tempo e contratempo - e, logo, fases e defasagens - que resultariam naquilo que a etnomusicologia denomina contrametricidade (Sandroni, 200I). Opera-se assim uma abertura na quadratura, que cede lugar a uma outra lógica, fundada na dialética entre duas ordens de acentuação simultâneas que a rítmica afro-europeia brasileira aciona: a do compasso binário, tensionada pela contrametricidade, e a da adição combinada de células pares e ímpares, que se abrigam e se subdividem, no entanto, no interior do compasso (Sandroni, 200I). Portanto, no encontro promovido pelo processo colonial, em solo ameríndio, entre as culturas da Europa e da diáspora africana de escravos, a música negra resistiu subterrânea e espertalhonamente à supremacia melódica europeia, justamente ao sincopá-la. Em outras palavras, embora se submetendo, incutia no sistema tonal europeu sua concepção temporal-cósmico-rítmica de modo a balançar por dentro suas fundações.

\section{CODA: ABRASILEIRAMENTO COSMOPOLITÍCO}

O Ensaio sobre música brasileira é expressão emblemática do esforço "mariodeandradeano" (para abrasileirar o hercúleo) de abrasileirar o Brasil, esforço centrado na necessidade de desfazer o divórcio entre a imaginação e o sentimento brasileiro (Botelho, 20I 2). Esse é, como sabemos, o tema de sua correspondência com, entre outros, o então jovem provinciano embriagado de literatura 
francesa Carlos Drummond de Andrade no início de sua amizade; tema que revisitaremos brevemente a fim de adensar a qualificação de certos elementos que fundamentariam sua visão cosmopolita de "nacional" e brasilidade. Drummond surgia a Mário como um Macunaíma, ou seja, como espécie de "monstro mole e indeciso", cuja desarmonia o assemelharia ao Brasil. Em carta datada de 22 de novembro de I924, o poeta mineiro havia desabafado para aquele que já reputava como o líder intelectual do modernismo:

Não sou ainda suficientemente brasileiro. Mas às vezes me pergunto se vale a pena a sê-lo. [...] Pessoalmente, acho lastimável essa história de nascer entre paisagens incultas e sob céus pouco civilizados [...] É que nasci em Minas, quando devera nascer [...] em Paris. O meio em que vivo me é estranho: sou um exilado. [...] O Brasil não tem atmosfera mental; não tem literatura; não tem arte; tem apenas uns políticos muito vagabundos e razoavelmente imbecis e velhacos. [...] O que todos nós queremos é obrigar este velho e imoralíssimo Brasil a incorporar-se ao movimento universal das ideias (Andrade, 2002: 56-57).

E recorria, na sequência, às célebres afirmações de Joaquim Nabuco (I976: 26-27), feitas em Minha formação, de que "o sentimento em nós é brasileiro, mas a imaginação europeia", e que o "Novo Mundo, para tudo o que é imaginação estética ou histórica é uma verdadeira solidão". Ironicamente, Mário observa ao jovem poeta na resposta a sua carta:

Você fala na "tragédia de Nabuco, que todos sofremos". Engraçado! Eu há dias escrevia numa carta justamente isso, só que de maneira mais engraçada de quem não sofre com isso. Dizia mais ou menos: "o doutor [Carlos] Chagas descobriu que grassava no país uma doença [transmitida pelos barbeiros] que foi chamada moléstia de Chagas. Eu descobri outra doença, mais grave, de que todos estamos infeccionados: a moléstia de Nabuco". É preciso começar esse trabalho de abrasileiramento do Brasil (Andrade, 2002: 70).?

Tal abrasileiramento não se confunde com nacionalismo; muito pelo contrário, significa "ter espírito religioso para com a vida" (Andrade, 2002: 46), conferir atenção e se relacionar intensamente com toda e qualquer manifestação dela. E é com gente chamada baixa e ignorante que se aprende a sentir e não com a inteligência e erudição livresca (Andrade, 2002: 48). Esse gesto de abertura para o outro, que é mais amplo em sua obra, visa conferir visibilidade, voz e agência a essa "gente", sem que tal "empatia" se dilua no fetiche de uma suposta autenticidade popular reificada, obnubilando a percepção da desigualdade social. A criação desse vínculo intenso com a vida implicaria justamente conciliar a imaginação e o sentimento brasileiro. Drummond confessa a Mário: "Sou acidentalmente brasileiro. [...] Sou hereditariamente europeu, ou antes: francês" (Andrade, 2002: 59). Mário também declara seu vínculo contingente com o Brasil, contudo, para justificar novamente a necessidade de "abrasileiramento" do mesmo: "Eu não amo o Brasil espiritualmente mais que à França ou à Cochinchina. Mas é no Brasil que me acontece viver" (Andrade, 2002: 5I). Ou ainda nos versos do poema "O poeta come amendoim" de Clã do Jaboti: 
Brasil amado não porque seja minha patria,

Patria é acaso de migrações e do pão-nosso onde Deus der...

Brasil que eu amo porque é o ritmo do meu braço aventuroso,

O gosto dos meus descansos,

O balanço das minhas cantigas amores e dansas.

Brasil que eu sou porque é a minha expressão muito engraçada,

Porque é o meu sentimento pachorrento,

Porque é o meu geito de ganhar dinheiro, de comer e de dormir.

Portanto, não se trata de repudiar sem mais a experiência europeia, como Drummond se admite incapaz de fazer, tampouco de desprezar a imitação e falsificação dos modelos estrangeiros. O que está em jogo para Mário na proposta de abrasileirar o Brasil é antes rejeitar o falso dilema nacionalismo versus universalismo: "não existe essa oposição entre nacionalismo e universalismo. O que há é mau nacionalismo: o Brasil pros brasileiros - ou regionalismo exótico. Nacionalismo quer simplesmente dizer: ser nacional. O que mais simplesmente ainda significa: Ser" (Andrade, 2002: 70), de modo que nenhuma forma da vida lhe seja indiferente. Continua Mário: "Ninguém que seja verdadeiramente, isto é, viva, se relacione com seu passado, com as suas necessidades imediatas práticas e espirituais, se relacione com o meio e com a terra, com a família etc., ninguém que seja verdadeiramente, deixará de ser nacional”. Para Mário, "nossos ideais não podem ser os da França porque as nossas necessidades são inteiramente outras, nosso povo outro, nossa terra outra. Nós seremos civilizados em relação às civilizações o dia em que criarmos o ideal, a orientação brasileira" (Andrade, 2002: 7I). Percebe-se, assim, que para o autor "ser brasileiro" consiste em adotar não apenas temário brasileiro, sempre sujeito a exotismo pitoresco e ao "mau nacionalismo" patriótico e xenófobo, como bem lembra em outros lugares, mas principalmente uma perspectiva brasileira, isto é, um modo próprio de se relacionar, de estar, sentir e pensar o mundo - tal como a dinâmica dos gestos, capturada nos versos citados, traduz em técnica e memória do corpo nexos socioculturais específicos (Arantes \& Arantes, I997: 84-94). O Brasil seria, portanto, “o passado guaçú e bonitão pesando em nossos gestos" (Andrade, I985: I50), o lugar não apenas em que nos acontece viver, mas que vive em nós de alguma forma. Eis aí talvez a chave do enigma da brasilidade em Mário de Andrade. Erradicar a "moléstia de Nabuco", essa doença tropical transmitida aos jovens pelo bacilo das ninfas europeias, significava não apenas evitar o despaisamento passivo e a macaqueação ingênita, mas promover a união da inteligência e do sentimento do Brasil, numa espécie de nacionalismo universalista: "De que maneira nós podemos concorrer para a grandeza da humanidade? É sendo franceses ou alemães? Não, porque isso já está na civilização. O nosso contingente tem de ser brasileiro. O dia em que nós formos inteiramente brasileiros e só brasileiros, a humanidade estará rica de mais uma raça, rica duma nova combinação de qualidades humanas" (Andrade, 
2002: 70). Afinal, "as raças são acordes musicais" - a ser usados na harmonia das civilizações. Não há Civilização, há civilizações. E, como lembra no Ensaio, os processos de harmonização sempre ultrapassam as nacionalidades (Andrade, I972: 49). É preciso "passar da fase do mimetismo para a fase da criação. E então seremos universais porque nacionais" (Andrade, 2002: 70). A vacina consistiria, assim, como assinala Silviano Santiago (2008: 27), em rechaçar a idealização e o recalque do passado nacional, para adotar como estratégia estética e economia política a inversão dos valores hierárquicos estabelecidos pelo cânone eurocêntrico. Essa estética política, necessariamente periférica, ambivalente e precária, compreende tanto o desrecalque localista da multiplicidade étnica e cultural das práticas populares abominadas pela elite quanto o nexo da nossa formação nacional com o pensamento universal não eurocêntrico. Atentando para o localismo do universal e o alcance universalista do local - isto é, sem reificar nem localismos em seu particularismo nem o universalismo em sua abstração -, Mário vira do avesso a perspectiva colonial. Não se trata, portanto, de substituir um discurso eurocêntrico por outro igualmente autocentrado e totalizante, mas de avançar uma concepção plural e cosmopolita de civilização, em que se podem apreciar tanto um canto novo tirado por um cantador anônimo do Nordeste quanto uma cantata de Bach. Trata-se de um tipo de polifonia potencialmente consonante mas não uníssona, na qual há lugar para o relacionamento mais democrático entre diferenças e com as histórias, as culturas e as pessoas do mundo e do próprio Brasil.

O novo corpo a corpo com o texto do Ensaio sobre música brasileira aqui perseguido demonstra que brasilidade, identidade nacional e nacionalismo não são necessariamente categorias intercambiáveis e estáveis no léxico e no projeto modernista de Mário de Andrade (recebendo, aliás, modulações de acordo com as conjunturas do contexto social e intelectual) (ver, a respeito, Botelho \& Hoelz, no prelo). Se a reflexão modernista sobre a brasilidade reconhece a modernidade como uma ordem universal e a afirmação desse ideal universalista se faz pela mediação do nacionalismo, como sugere Eduardo Jardim (Moraes, I983: 25), igualmente a afirmação do nacional depende da mediação do universal, como pondera Carlos Sandroni (I988: I I). Como procuramos desenvolver nesta leitura a contrapelo - ou com Macunaíma a contracanto -, se, por um lado, a ideia de brasilidade deve ser encarada dentro de um movimento mais amplo de sentido cosmopolita, no qual o lugar da cultura brasileira na ordem moderna e universal é definido a partir de uma relação, por outro, seus significado e sentido trazem uma nota crítica e dissonante em relação ao contexto modernista e não se deixam domesticar inteiramente pelo paradigma nacionalista que então se impunha nem se subsumem a uma ideia de identidade nacional unitária e homogênea que se tornaria hegemônica nos anos I930, ainda que digam respeito à lógica complexa de mobilização e reivindicação das identidades coletivas (Eder, 2003). Vimos que, justamente por não reificar constelações ontológicas 
nacionais ou regionais como se fossem regidas por lógicas autônomas e/ou pudessem encarnar paradigmas refratários e alternativos a uma matriz civilizacional supostamente unitária - europeia, ocidental, metropolitana, do norte, ou como quer que se queira chamá-la hoje -, essa espécie de "entrelugar" da brasilidade permitiria desconstruir os pressupostos de homogeneidade e pureza de qualquer identidade social. Ao contrário, parecem estar em jogo nessa ideia precisamente as relações de diferença, por certo carregadas de contradição e assimetria, entre particular e universal, local e cosmopolita, e não as essências, como também vem propondo André Botelho (2012). Trata-se de relações que, embora originalmente configuradas num registro de nacionalismo militante, codificam indagações, aspirações e proposições para além dele: da sociedade brasileira e das experiências culturais aqui elaboradas com sua diversidade interna e com o mundo; de processos de diferenciação com processos de homogeneização; de diferenças culturais com desigualdades sociais. Compartilham, assim, problemas ligados aos desafios da solidariedade social no contexto contemporâneo de pluralização de identidades coletivas subnacionais e supranacionais. Se os padrões identitários compactos, centrados e autorreferidos sempre foram um patrimônio ideológico zelosamente guardado por forças totalitárias e autocráticas (Cohn, 20I6), a concepção de identidade aberta, dialógica e em devir que vislumbramos em Mário de Andrade encerra potência crítica para o aprofundamento de formas de convivência democráticas em que as pessoas e grupos se orientem não para a competição ou o antagonismo, mas para as exigências legítimas de outros antes de para as suas próprias. Ao elaborar uma perspectiva brasileira e cosmopolita, relacional e descentrada sobre o Brasil e o mundo, sobre "ruínas de linhas puras", Mário abre uma via fecunda de interpelação ao presente, acenando para a possibilidade de (re)elaborarmo-nos na relação com o outro, reconhecendo o(s) "nós" no eu.

Recebido em I/I I/20I7 | Revisto em 3/3/2018 | Aprovado em Io/3/20I8

Maurício Hoelz é mestre e doutor pelo Programa de Pós-Graduação em Sociologia e Antropologia da UFRJ, onde atualmente realiza pósdoutorado pelo PNPD/Capes, e editor executivo de Sociologia \& Antropologia. Publicou recentemente, em coautoria com André Botelho, "O mundo é um moinho: sacrifício e cotidiano em Mário de Andrade" (20I6) e "Macunaíma contra o Estado Novo: Mário de Andrade e a democracia" (Novos Estudos Cebrap, no prelo). 


\section{NOTAS}

I A grafia original de Mário de Andrade foi mantida nas citações.

2 Ver, por exemplo, a discussão acerca do primitivismo na correspondência com Renato de Almeida (Nogueira, 2003: I34 Ss.)

3 Para uma reconstituição detalhada dessa circunstância remetemos o leitor ao trabalho de Lisbôa (20I5). Tomando - Ensaio como resultado de um acúmulo de pesquisa e reflexão ao longo da década, o autor realiza investigação pormenorizada sobre sua gênese e estrutura. Para tanto, vale-se da correspondência e de textos anteriores (que nomeia "ensaios do Ensaio") como vias de acesso ao processo de elaboração das ideias - reúne pistas, desse modo, sobre a origem das melodias, as encomendas aos amigos e a coleta por eles feita etc. O estudo perfaz um mapeamento: do universo de compositores eruditos e populares referidos (além do conjunto Os Oito Batutas, cita 8I compositores, dos quais 59 são estrangeiros, e 22, brasileiros), indicando sua ordem de preponderância (Villa-Lobos, Lorenzo Fernandez e Luciano Gallet ocupam o pódio); da representatividade dos tipos de composições de acordo com gênero (desde óperas, passando pelo repertório sinfônico até conjuntos de câmara e peças para piano solo) e proveniência geográfica; da rede de colaboradores, também geograficamente variada, que enviava a Mário de Andrade documentos musicais. Além disso, o analista reconstrói o repertório mobilizado - em larga medida desconhecido hoje -, situando-o no seu contexto sincrônico, e detém-se nas diferenças entre as edições do livro, ainda que sem tirar consequências analíticas desse procedimento. Se o trabalho se mostra fundamental na restituição das circunstâncias contingentes de produção do Ensaio, paradoxalmente, no entanto, arrisca-se a incorrer numa leitura teleológica ao recuperar os "ensaios do Ensaio" para argumentar que o trabalho de pesquisa sobre as canções populares neles elaborados desaguariam no livro de I928. O risco de entendê-lo como ponto de chegada de um processo e não como parte do processo é justamente o de subtrair-lhe seu caráter aberto, contingente. 
4 Manuel Bandeira conta a Mário que o jornal A Pátria havia lhe pedido que respondesse se "Há uma arte autenticamente brasileira?". A resposta dele: "Nos melhores poetas brasileiros de agora há esse sentimento forte de brasilidade. Não patriotada abstrata, mas uma funda ternura pela terra e coisas da terra. Ternura criadora. Mário de Andrade é o que foi mais longe e mais fundo até agora. [...] O brasileirismo de Mário de Andrade não é primitivismo nem regionalismo: situa-se na cultura universal e é mesmo fruto de uma espécie de integração cultural" (Andrade, 2000: 236).

5 Exemplo desse procedimento pode ser visto na poética de Paulicéia Desuairada (I922), primeiro livro de poesias no Brasil a difundir os princípios estéticos das vanguardas europeias, além de sistematizar o uso do verso livre. Como sustenta Lopez (I996: I8), nele começa a se estruturar o trabalho de digerir e transformar, visando à adequação - verdadeiro crivo crítico que seleciona -, verificando a convivência das variadíssimas propostas das vanguardas europeias. A filtragem converte a influência em perspectiva crítica de criação. Não à toa, o "Arlequim" seria o motivo que organiza esteticamente o livro e a colagem, a forma que trabalha estruturalmente na poesia as costuras do arlequim.

6 A primeira versão rascunhada desse estudo intitula-se "A influência portuguesa na música popular brasileira" e foi recolhida por Oneyda Alvarenga em As melodias do boi e outras peças. A memória enviada ao Congresso de Praga é uma versão enxugada para se adequar ao tempo estipulado pelo congresso e foi publicada em Música, doce música.

7 Esse trabalho de tornar o Brasil brasileiro ganha expressão emblemática na adoção programática da língua portuguesa falada no Brasil e sua transposição para a escrita que aparece nos poemas, romances e ensaios de Mário de Andrade. Nessa aproximação, Mário de Andrade se opunha à distinção entre norma culta e a língua portuguesa falada, adaptada e recriada no cotidiano brasileiro. 


\section{REFERÊNCIAS BIBLIOGRÁFICAS}

Alvarenga, Oneyda. (1974). Mário de Andrade, um pouco. Rio de Janeiro: José Olympio.

Andrade, Carlos Drummond de. (2002). Carlos \& Mário: correspondência entre Carlos Drummond de Andrade e Mário de Andrade: I924-I945. Rio de Janeiro: Bem-te-Vi.

Andrade, Mário de. (2000). Correspondência Mário de Andrade \& Manuel Bandeira. Organização, introdução e notas Marcos Antonio de Moraes. São Paulo: Edusp/IEB.

Andrade, Mário de. (1989). Dicionário musical brasileiro. Organizado por Flávia Toni e Oneyda Alvarenga. São Paulo/Brasília: IEB/Ministério da Cultura.

Andrade, Mário de. (1985). Cartas de Mário de Andrade a Prudente de Moraes Neto I924-I936. Organizado por Georgina Koifman. Rio de Janeiro: Nova Fronteira.

Andrade, Mário de. (1976a). Táxi e crônicas no Diário Nacional. Estabelecimento de texto, introdução e notas de Telê Porto Ancona Lopez. São Paulo: Duas Cidades; Secretaria da Cultura, Ciência e Tecnologia.

Andrade, Mário de. (I976b). Música, doce música. São Paulo/ Brasília: Martins/MEC.

Andrade, Mário de. (I976c). O turista aprendiz. Estabelecimento de texto, introdução e notas de Telê Porto Ancona Lopez. São Paulo: Duas Cidades/Secretaria da Cultura, Ciência e Tecnologia.

Andrade, Mário de. (1974). Aspectos da literatura brasileira. 5 ed. São Paulo/Brasília: Martins/INL.

Andrade, Mário de. (1972). Ensaio sobre música brasileira. 3 ed. São Paulo/Brasília: Martins/INL.

Arantes, Otília \& Arantes, Paulo. (I997). Sentido da formação: três estudos sobre Antonio Candido, Gilda de Mello e Souza e Lúcio Costa. São Paulo: Paz e Terra.

Batista, Marta ; Lopez, Telê Ancona \& Lima, Yone Soares de (orgs.). (I972). Brasil: I ${ }^{\circ}$ tempo modernista: I9I7-I929. Documentação. São Paulo: Instituto de Estudos Brasileiros.

Botelho, André. (2017). O modernismo como movimento cultural. Projeto CNPq. (mimeo).

Botelho, André. (20I2). De olho em Mário de Andrade: uma descoberta intelectual e sentimental do Brasil. São Paulo: Claro Enigma. 
Botelho, André. (2010). Passado e futuro das interpretações do país. Tempo Social, 22, p. 47-66.

Botelho, André \& Hoelz, Maurício. (2018). Macunaíma contra o Estado Novo. Novos Estudos Cebrap, no prelo.

Candido, Antonio. (1995). Uma palavra instável. In: Vários escritos. São Paulo: Duas Cidades, p. 299-30I.

Candido, Antonio. (I980). Intervenção num debate sobre Paulo Emílio. Filme Cultura, Embrafilme, 35/36.

Cohn, Gabriel. (2016). Weber, Frankfurt: teoria e pensamento social I. Rio de Janeiro: Azougue.

Coli, Jorge. (I990). Mário de Andrade e a música. In: Berriel, C. E. (org.), Mário de Andrade hoje. São Paulo: Ensaio.

Contier, Arnaldo Daraya. (2010). Mário de Andrade e a utopia do som nacional. Trama Interdisciplinar, I/2, p. 73-95.

Contier, Arnaldo Daraya. (I995). O "Ensaio sobre a Música Brasileira": estudo dos matizes ideológicos do vocabulário social e técnico-estético (Mário de Andrade, I928). Revista Música, 6/I-2, p. 75-I2I.

Eder, Klaus. (2003). Identidades coletivas e mobilização de identidades. Revista Brasileira de Ciências Sociais. I8/53.

Ferguson, James. (2006). Global shadows: Africa in the neoliberal world order. Durhan/London: Duke University Press.

Garramuño, Florencia. (2009). Modernidades primitivas: tango, samba e nação. Belo Horizonte: Ed. UFMG.

Hamilton-Tyrrell, Sarah. (2005). Mário de Andrade, Mentor: Modernism and Musical Aesthetics in Brazil, I920-I945. Musical Quarterly, 88/I, p. 7-34.

Hoelz, Maurício. (2015a). Entre piano e ganzá: música e interpretação do Brasil em Mário de Andrade. Tese de Doutorado. PPGSA/Universidade Federal do Rio de Janeiro.

Hoelz, Maurício. (20I5b). Na pancada do ganzá e a racionalização da música ocidental. Brasiliana - Journal for Brazilian Studies, 4/I, p. 7-32.

Lisbôa, Sérgio Rodrigues. (20I5). Da Bucólica ao Ensaio sobre Música Brasileira. Dissertação de Mestrado. PPGM/ECA/USP.

Lopez, Telê Ancona. (1996). Mariodeandradeando. São Paulo: Hucitec.

Lopez, Telê Ancona. (1972). Mário de Andrade: ramais e caminhos. São Paulo: Duas Cidades. 
Luper, Albert. (1965). The musical thought of Mário de Andrade (I893-1945). Yearbook Inter-American Institute for Musical Research, I, p. 4I-54.

Mello e Souza, Gilda de. (2003). O tupi e o alaúde. São Paulo: Duas Cidades/Ed. 34.

Moraes, Eduardo Jardim. (1983). A constituição da ideia de modernidade no modernismo brasileiro. Tese de Doutorado (Filosofia). IFCS/UFRJ.

Moraes, Marcos Antonio de. (2007). Orgulho de jamais aconselhar: a epistolografia de Mário de Andrade. São Paulo: Edusp/ Fapesp.

Moreschi, Marcelo. (20Io). A façanha auto-historiográfica do modernismo brasileiro. Tese de Doutorado. Hispanic Languages and Literatures/University of California, Santa Barbara. Nabuco, Joaquim. (1976). Minha formação. Rio de Janeiro/Brasília: José Olympio/INL.

Nogueira, Maria Guadalupe Pessoa. (2003). Edição anotada da correspondência Mário de Andradee Renato de Almeida. Dissertação demestrado. Programa de Teoria Literária eLiteratura Comparada, Faculdade de Filosofia/Universidade de São Paulo.

Sandroni, Carlos. (200I). Feitiço decente. Rio de Janeiro: Zahar. Sandroni, Carlos. (1988). Mário contra Macunaíma. São Paulo: Vértice.

Santiago, Silviano. (2008). O cosmopolitismo do pobre. Belo Horizonte: Ed. UFMG.

Schorske, Carl E. (1988). Viena fin-de-siècle: política e cultura. Tradução de Denise Bottman. São Paulo: Companhia das Letras.

Teixeira, Maurício de Carvalho. (2007). Torneios Melódicos: poesia cantada em Mário de Andrade. Tese de doutorado. Departamento de Letras Clássicas e Vernáculas, Faculdade de Filosofia, Letras e Ciências Humanas, Universidade de São Paulo.

Toni, Flávia Camargo. (20I5). A primeira fase de Ariel, uma revista de música. Revista Música Hodie, Goiânia, I5/I, p. I54-I70.

Wisnik, José Miguel. (2003). Machado maxixe: o caso Pestana. Teresa. Revista de Literatura Brasileira, 4/5, p. I3-79.

Wisnik, José Miguel. (1979). Dança dramática (poesia/música brasileira). Tese de Doutorado. FFLCH-USP. 
Palavras-chave

Mário de Andrade;

Ensaio sobre música brasileira; nacionalismo; identidade nacional; cultura brasileira.

Keywords

Mário de Andrade; Ensaio sobre música brasileira; nationalism; national identity; Brazilian culture.

\section{O ESPELHO DE MACUNAÍMA:}

\section{O ENSAIO SOBRE MÚSICA BRASILEIRA PARA}

\section{ALÉM DO NACIONALISMO}

\section{Resumo}

O artigo propõe um estudo analítico e a contrapelo do Ensaio sobre música brasileira de Mário de Andrade, publicado no final de 1928 e frequentemente considerado peça ideológica exemplar de rotinização de seu projeto nacionalista. Argumenta que o foco sobre a dimensão normativa acabou por cronicamente minimizar, senão eclipsar, a dimensão propriamente cognitiva do texto, obliterando as visões instrumental de nacionalismo e aberta de identidade aí formuladas ao discipliná-lo a partir do paradigma, que se tornaria hegemônico nos anos I930, da unidade nacional e de uma cultura brasileira autêntica e homogênea. Sugere ainda que a ideia cosmopolita e descentrada de brasilidade do modernista expressa uma identidade aberta, plural e inacabada capaz de provocar o reconhecimento da cultura popular e da dignidade de seus portadores sociais.

\section{MACUNAÍMA'S MIRROR: BEYOND NATIONALISM} IN THE ENSAIO SOBRE A MÚSICA BRASILEIRA

\section{Abstract}

The article undertake an against-the-grain study of Mario de Andrade's Ensaio sobre música brasileira, published at the end of 1928 and frequently taken to be a key ideological piece in the routinzation of his nationalist project. It argues that a focus on the normative dimension came to chronically minimize, when not actually eclipse, the more properly cognitive dimension of the text, eradicating its instrumental view of nationalism and open view of identity by making it conform to the paradigm - which would become hegemonic during the I930s - of national unity and of an authentic and homogenous Brazilian culture. It also suggests that the cosmopolitan and decentred idea of "Brazilianness" expressed by the Modernist author conveys an open, plural and unfinished conception of identity, which enables us to recognize popular culture and the dignity of its social bearers. 